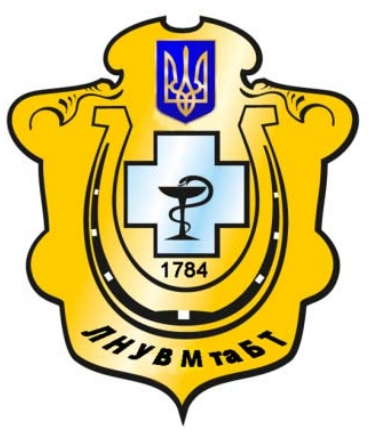

Науковий вісник Львівського національного університету ветеринарної медицини та біотехнологій імені С.3. Гжицького

Scientific Messenger of Lviv National University of Veterinary Medicine and Biotechnologies named after S.Z. Gzhytskyj

doi:10.15421/nvlvet7136

ISSN 2413-5550 print

ISSN 2518-1327 online

$\underline{\text { http://nvlvet.com.ua/ }}$

УДК 619:618: 619: 616.07

\title{
Діагностичний етап гінекологічної диспансеризації неплідних корів
}

\author{
О.А. Кацараба, О.Я. Дмитрів, Є.С. Костишин, Р.М. Івашків, І.М. Кудла Р.М. Сачук* \\ navchalnavet@mail.ru
}
Львівський національний університет ветеринарної медицини та біотехнологій імені С.3. Гжиџького, вул. Пекарська, 50, м. Львів, 79010, Україна;
*Дослідна станиія епізоотологї IВМ НААН,
вул. Князя Володимира, 16/18, 33024, Рівне, Україна

\begin{abstract}
Проблема акушерської та гінекологічної патології стоїть на одному з перших місць серед незаразних захворювань тварин. Для усунення даної проблеми в Україні розроблена диспансеризація корів, щзо включає комплекс діагностичних, лікувальних і профілактичних заходів, спрямованих на відтворення стад здорових тварин .

Важливе значення у профілактичі гінекологічної патології відводиться плановій диспансеризачії, одним із етапів якої $\epsilon$ дослідження крові. Своєчасне проведення таких досліджень дозволяє виявляти субклінічні форми гінекологічних захворювань, призначати групове використання засобів етіотропної, замінної та патогенетичної терапії. Досліджено показники крові неплідних корів на 2 - 3 місяиі після отелення. Встановлено, щя підвищення у крові корів вмісту сіалових кислот вище 253,0 у.о., ииркулюючих імунних комплексів вище 16,0 у.о., рівня малонового диальдегіду вище 8,14 мкмоль/л, дієнових кон'югатів вище 2,11 мкмоль/л та молекул середньої маси більще 1,05 свідчить про перебіг запального прочесу в статевій системі та зумовлену цим симптоматичну неплідність.

Ключові слова: гінекологічна патологія, кров, загальний білок, сіалові кислоти, перекисне окиснення ліпідів, ииркулюючі імунні комплекси.
\end{abstract}

\section{Диагностический этап гинекологической диспансеризации бесплодных коров}

\author{
О.А. Кацараба, О.Я. Дмытрив, Е.Е. Костишин, Р.М. Ивашкив, И.М. Кудла, Р.М. Сачук* \\ navchalnavet@mail.ru
}
Львовский национальный университет ветеринарной медицины и биотехнологий имени С.3. Гәицкого, ул. Пекарская, 50, г. Львов, 79010, Украина
* Исследовательская станциия эпизоотологии ИВМ НААН, ул. Князя Владимира, 16/18, 33024, Ровно, Украина

\begin{abstract}
Проблема акушерской и гинекологической патологии стоит на одном из первых мест среди незаразных заболеваний животных. Для устранения данной проблемы в Украине разработана диспансеризачия коров, включающий комплекс диагностических, лечебных и профилактических мероприятий, направленных на создание стад здоровых животных. Важное значение в профилактике гинекологической патологии отводится плановой диспансеризации, одним из этапов которой является исследование крови. Своевременное проведение таких исследований позволяет выявлять субклинические формы нарушения обмела веществ, назначать, заменяющей и патогенетической терапии. Поэтому следующим нашим заданием при проведении гинекологической диспансеризации коров было изучить показатели крови бесплодных коров на 2 - 3 месяиах после отела по сравнению с коровами, которые проявили характерные признаки стадии возбуждения полового цикла. Установлено, что повышение в крови коров содержания сиаловых кислот выше 253,0 у.е., ииркулирующих иммунных комплексов выше 16,0 у.е., уровня малонового диальдегида выше 8,14 мкмоль/л, действует новых конъюгатов выше 2,
\end{abstract}

\section{Citation:}

Katsaraba, O.A., Dmytriv, O.J., Kostyshyn, Ye.Ye., Ivashkiv, R.M., Kudla, I.M., Sachuk, R.M. (2016). Diagnostic stage gynecological clinical examination infertile cows. Scientific Messenger LNUVMBT named after S.Z. Gzhytskyj, 18, 3(71), $163-166$. 
11 мкмоль/л и молекул средней массы более 1,05 свидетельствует о течении воспалительного проиесса в половой системе и обусловленное тем самым симптоматическое бесплодие.

Ключевые слова: гинекологическая патология, кровь, общий белок, сиаловые кислоты, перекисное окисление липидов, циркулирующие иммунные комплексы.

\title{
Diagnostic stage gynecological clinical examination infertile cows
}

\author{
O.A. Katsaraba, O.J. Dmytriv, Ye.Ye. Kostyshyn, R.M. Ivashkiv, I.M. Kudla, R.M. Sachuk \\ navchalnavet@mail.ru \\ Lviv National University of Veterinary Medicine and Biotechnologies named after S.Z. Gzhytskyi, \\ Pekarska Str., 50, Lviv, 79010, Ukraine; \\ Research Epizootology Station IVM NAAS, \\ Knyaz Vladimir Str., 16/18, 33024, Rivne, Ukraine
}

The problem of obstetric and gynecological pathology is one of the first places among non-communicable animal diseases. To resolve this problem in Ukraine cows developed clinical examination, which includes a set of diagnostic, therapeutic and preventive measures aimed at creating healthy herds of animals.Equally important in preventing gynecological pathology given the planned health center, one of the stages of which are blood tests. Timely such studies can detect subclinical forms of metabolic disorders, prescribe the use of causal group, replaceable and pathogenetic therapy. Therefore, followin gour task during obstetric clinical examination cows to study blood parameters in fertile cows for $2-3$ months after calving compared with cows that showed characteristic signs of sexual arousal stage of the cycle. It was established that the increase in blood cows sialic acids content above 253.0 USD, circulating immune complexes above 16.0 c.u., malondialdehyde levels above $8.14 \mathrm{mmol} / \mathrm{L}$, diene conjugates above 2,11 $\mathrm{mmol} / \mathrm{l}$ and the average molecular weight of more than 1.05 indicates the course of inflammation in the development of sexual system and infertility.

Key words: obstetric-gynecologicalpathology, blood, wholeprotein, sialicacids, lipidperoxidation, circulating immune complexes.

\section{Вступ}

У зв'язку із впровадженням у скотарство промислової технології утримання великої кількості тварин на фоні інтенсивного їхнього використання, виникає необхідність організації постійного систематичного контролю за станом здоров'я й відтворною функції тварин, своєчасного проведення лікувальних і профілактичних заходів (Huesto, 1990; Kalter et al., 1990; Jablonski et al., 2006). В основі диспансеризації лежить систематичне й поглиблене клінічне, біохімічне й спеціальне профілактичне обстеження всього поголів'я $з$ раннім застосуванням ізоляції й лікування, усунення факторів зовнішнього середовища, що негативно діють на здоров'я й продуктивність корів, систему раціональної годівлі, утримання й догляду за тваринами (Zvereva et al., 1989; Kaplinskyy, 2000; Zvereva et al., 2001). Виявити причини і визначити вплив кожної 3 них на весь організм і статеві органи зокрема - основне завдання фахівця ветеринарної медицини. Це можливе лише при умові усестороннього і глибокого аналізу результатів загального клінічного, ректального і вагінального дослідження тварин, оцінки результатів лабораторного дослідження крові, виділень із статевих органів, мазків - відбитків із слизової оболонки піхви (Zvereva et al., 1989; Haruta, 1995). Важливе значення у профілактиці гінекологічної патології відводиться гінекологічній диспансеризації, одним із етапів якої є дослідження крові. У практику ветеринарної медицини надійно увійшли і закріпились як загальноприйняті методи визначення загального білка в сироватці крові, кислотної ємності, загального кальцію, неорганічного фосфору, каротину, кетонових тіл, глюкози (Levchenko et al., 2002). Своєчасне проведен- ня таких досліджень дозволяє виявляти субклінічні форми порушення обміну речовин, призначати групове використання засобів етіотропної, замінної та патогенетичної терапії.

Метою нашої роботи було вивчити показники крові неплідних корів на $2-3$ місяці після отелення у порівнянні 3 коровами, які проявляли характерні ознаки стадії збудження статевого циклу, а за отриманими даними визначити діагностичні показники крові, які можуть бути використані у виявленні неплідних корів.

\section{Матеріал і методи досліджень}

Дослід проведено на коровах української молочної чорно-рябої породи в ТзОВ «Агропродсервіс-Інвест» Козівського району Тернопільської області. Для проведення досліду сформовано групу 3 клінічно здорових корів $(\mathrm{n}=10)$ та групу неплідних корів $(\mathrm{n}=10)$. Кров для дослідження брали 3 яремної вени і досліджували у лабораторії акушерства та гінекології Тернопільської дослідної станції ІВМ НААН. Вміст сіалових кислот досліджено за Гессом, малоновий диальдегід - за реакцією з тіобарбітуровою кислотою (Placer L., 1998), вміст загального білка - за біуретовою реакцією (Chromi V., Fischer J., 1990), дієнових кон'югатів - екстракцією гептан-ізопропиловим спиртом, молекул середньої маси за абсорбцією кислоторозчинної фракції в монохроматичному світловому потоці при довжині хвиль 254 нм і 280 нм, загальний вміст білків у сироватці крові - за біуретовою реакцією, білкові фракції - нефелометричним методом (Kondrahyn et al., 2004; Vlizlo et al., 2012). Статистичну обробку результатів проведено 3 використан- 
ням стандартних комп'ютерних програм. Різницю між двома величинами вважали вірогідною за * $-\mathrm{P}<0,05$; ** $-\mathrm{P}<0,01 ; * * *-\mathrm{P}<0,001$ (Lakyn, 1990).

\section{Результати та їх обговорення}

Проведені нами дослідження показали, що у неплідних корів вміст загального білка був нижчим на $8,4 \%(\mathrm{P}<0,05)$, на фоні підвищення відсотка $\alpha-$ глобулінів на $13,4 \%(\mathrm{P}<0,05)$ та $\beta$-глобулінів на $17,2 \%(\mathrm{P}<0,05)$ у порівнянні з клінічно здоровими тваринами (табл. 1).

Отримані нами дані щодо вмісту загального білка i його фракцій в крові неплідних корів свідчать про хронічний перебіг захворювання.

Табличя 1

Вміст загального білка і його фракцій у крові клінічно здорових та неплідних корів, $(M \pm \mathbf{m}, \mathbf{n}=10)$

\begin{tabular}{|c|c|c|c|}
\hline \multirow{2}{*}{\multicolumn{2}{|c|}{ Показники }} & \multicolumn{2}{|c|}{ Групи тварин } \\
\hline & & $\begin{array}{c}\text { Клінічно } \\
\text { здорові }\end{array}$ & Неплідні \\
\hline \multicolumn{2}{|c|}{ Загальний білок, г/л } & $81,10 \pm 1,25$ & $74,80 \pm 1,14^{*}$ \\
\hline \multicolumn{2}{|c|}{ Альбуміни,\% } & $46,71 \pm 0,79$ & $46,06 \pm 1,36$ \\
\hline \multirow{3}{*}{$\begin{array}{c}\text { Глобуліни, } \\
\text { \% }\end{array}$} & $\alpha$ & $12,14 \pm 0,61$ & $14,02 \pm 0,37^{*}$ \\
\hline & $\beta$ & $10,12 \pm 0,61$ & $12,22 \pm 0,33^{*}$ \\
\hline & $\gamma$ & $29,07 \pm 0,56$ & $29,06 \pm 0,32$ \\
\hline
\end{tabular}

Примітка: ${ }^{*} P<0,05$ - порівняно до клінічно здорових корів

Показником запального процесу в організмі корів $\epsilon$ підвищений вміст сіалових кислот у крові. Слід зазначити, що сіалові кислоти беруть участь у забезпеченні адгезії між клітинами, а також між клітинами i субстратом. Цей процес відіграє важливу роль у формуванні тканин і органів у період ембріогенезу. Сіалові кислоти виконують функцію захисту слизових оболонок дихального, кишкового та статевого шляхів.

Одним із механізмів імунологічного контролю за станом внутрішнього середовища організму тварин $\epsilon$ видалення з нього екзо-ендогенних антигенів шляхом утворення циркулюючих імунних комплексів (ЦІК) є одним із критеріїв оцінки імунного статусу організму, який, у свою чергу, корелює $з$ тяжкістю захворювання, відображає стан роботи ретикуло-ендотеліальної системи.

Табличя 2

Вміст сіалових кислот і ЦІК у крові клінічно здорових та неплідних корів, $(\mathbf{M} \pm \mathbf{m}, \mathbf{n}=\mathbf{1 0})$

\begin{tabular}{|c|c|c|}
\hline \multirow{2}{*}{ Показники } & \multicolumn{2}{|c|}{ Групи тварин } \\
\cline { 2 - 3 } & $\begin{array}{c}\text { Клінічно здо- } \\
\text { рові }\end{array}$ & Неплідні \\
\hline $\begin{array}{c}\text { Сіалові кислоти, } \\
\text { у.о. }\end{array}$ & $200,04 \pm 10,04$ & $253,01 \pm 10,42^{*}$ \\
\hline ЦІК, у.о. & $10,81 \pm 0,79$ & $16,34 \pm 0,89^{* *}$ \\
\hline
\end{tabular}

Примітка: ${ }^{*} P<0,05, \quad * * P<0,001-$ порівняно до клінічно здорових корів

3 наведених у табл. 2 даних видно, що у крові неплідних корів вміст сіалових кислот $є$ вищий на 20,94\% (Р < 0,05), а циркулюючих імунних комплексів на $33,9 \%(\mathrm{P}<0,001)$ проти клінічно здорових.

Інтенсифікацію пероксидного окиснення ліпідів (ПОЛ) вважають важливою складовою оксидантного стресу, що відіграє значну роль у патогенезі багатьох захворювань. 3 процесами ПОЛ безпосередньо пов'язані неспецифічні адаптаційні реакції організму, швидкість клітинного поділу, робота ферментних систем, регулювання проникності мембран тощо.

При проведені акушерсько-гінекологічної диспансеризації нами встановлено, що у крові неплідних корів підвищувався вміст малонового диальдегіду на $37,0 \%$ (Р < 0,05), а дієнових кон'югатів на 26,6\% $(\mathrm{P}<0,05)$, що свідчить про зниження активності системи захисту їх організму та активації процесів ПОЛ (табл. 3). Внаслідок накопичення продуктів ПОЛ в організмі неплідних корів на 22,9\% $(\mathrm{P}<0,05)$ зростав рівень молекул середньої маси, що свідчить про незначну ендогенну інтоксикацію організму тварин.

Таблиия 3

Показники ПОЛ та вміст молекул середньої маси у крові клінічно здорових і неплідних корів, $(\mathbf{M} \pm \mathbf{m}, \mathbf{n}=\mathbf{1 0})$

\begin{tabular}{|c|c|c|}
\hline \multirow{2}{*}{ Показники } & \multicolumn{2}{|c|}{ Групи корів } \\
\cline { 2 - 3 } & $\begin{array}{c}\text { Клінічно } \\
\text { здорові }\end{array}$ & Неплідні \\
\hline $\begin{array}{c}\text { Малоновий диальдегід, } \\
\text { ммоль/л }\end{array}$ & $5,46 \pm 0,12$ & $8,14 \pm 0,46^{*}$ \\
\hline $\begin{array}{c}\text { Діснові кон'югати, } \\
\text { мкмоль/л }\end{array}$ & $1,55 \pm 0,02$ & $2,11 \pm 0,07^{*}$ \\
\hline $\begin{array}{c}\text { Молекули середньої } \\
\text { маси, у.о. }\end{array}$ & $0,81 \pm 0,02$ & $1,05 \pm 0,01^{*}$ \\
\hline
\end{tabular}

Примітка: *P<0,05 порівняно до клінічно здорових корів

\section{Висновки}

Підсумовуючи результати дослідження показників крові неплідних та клінічно здорових корів за методикою гінекологічної диспансеризації, ми встановили:

1) У всіх дослідних неплідних корів діагностували ознаки хронічного перебігу гінекологічних захворювань, що призводило до розвитку інтоксикації організму.

2) Встановлено алгоритми біохімічних показників сироватки крові у неплідних корів для діагностичного етапу гінекологічної диспансеризації, зокрема:

- Підвищення вмісту сіалових кислот вище 253,0 у.о. та циркулюючих імунних комплексів вище 16,0 у.о.;

- Підвищення рівня малонового диальдегіду вище 8,14 мкмоль / л, дієнових кон'югатів вище 2,11 мкмоль / л та молекул середньої маси більше 1,05 y.o.

\section{Бібліографічні посилання}

Jablonski, V.A., Khomyn, S.P., Kalinowski, G.M. (2006). Veterinary obstetrics, gynecology and animal reproduction biotechnology with the basics of andrology. Tutorial. - Ball: NewBook (in Ukrainian).

Kaplinskyy, V.V. (2000). Reproductive function and resistance to obstetricand gynecological pathology of cattle due to polymorphism of serum proteins: Author. Thesis. on competition sciences. Degree candidate. vet. Sciences spets.16.00.07 «Veterinary Obstetrics». Lviv State Academy of Veterinary Medicine S.Z. Gzhytsky. Lviv, 19 (in Ukrainian). 
Huesto, W.D. (1990). The national animal health monitoring systems: addresising animal health information need in the USA. Pres. Veter.Med. 8,2/3, 97-102.

Kalter, R.J., Scidmore, A.L., Ferguson, J.D., Sniffen, C.J. (1990). Development of an expect system for management of dairy farms. J. Dairy Sci. 73, 162.

Zvereva, G.V., Yablonsky, V.A., Kosenko, M.V. (2001). Rekomendatsiyi prevention of infertility cattle. K.: Science. World (in Ukrainian).

Zvereva, G.V., Khomyn, S.P., Oleskyv, V.N. (1989). Metodyka akusherskoy and hynekolohycheskoy dyspanseryzatsyy cows and telok: Guidelines for listeners Increase qualifications of faculty, students, professionals and vetvrachey. Lviv: Lvovskyy zoovet in-t (in Russian).

Haruta, G.G. (1995). Clinical and laboratory methods for predicting reproductive function of cows: Author.
Thesis. for obtaining Dr.vet. Sciences specials. 16.00.07 «Veterinary Obstetrics and reproduction biotechnology». Lviv (in Ukrainian).

Levchenko, V.I., Sokolyuk, V.M., Bezukhetal, V.M. (2002). Research the blood of animals and clinical interpretation of the results. White Church (in Ukrainian).

Kondrahyn, I., Arkhipov, A.P., Levchenko, V.I. (2004). Methods veterynarnoy klynycheskoy laboratory diagnosis. M .: Colossus (in Ukrainian).

Vlizlo, V.V., Fedoruk, R.S., Ratych, I.B. (2012). Laboratori metody doslidzhen' u biologii', tvarynnyctvi ta veterynarnij medycyni [Tekst]: dovidnyk. L'viv: SPOLOM (in Ukrainian).

Lakyn, G.F. (1990). Biometric. M .: Higher School (in Russian).

Стаття надійшла до редакиії 25.09.2016 